\title{
Identifikasi Etnomatsains pada Tradisi Gunungan di Kraton Yogyakarta
}

\author{
Nuri Hidayati ${ }^{1 *}$, Amin Yoga Rahmawati ${ }^{1}$, Isti Khomah ${ }^{2}$, Ahmad Anis Abdullah ${ }^{1}$ \\ ${ }^{1}$ Program Studi Pendidikan Matematika, FKIP, Universitas Alma Ata \\ ${ }^{2}$ Program Studi Pendidikan Guru SD, FKIP, Universitas Alma Ata \\ *Email: nurihidayati@uaa.ac.id
}

DOI: https://doi.org/10.33369/pendipa.4.3.52-59

\begin{abstract}
The learning process in the 2013 curriculum which was revised in 2017 emphasizes learning that is fun, meaningful, and motivates students to be active. Based on these conditions, it is necessary to develop learning methods. So, it is necessary to have a learning innovation that uses a cultural approach by linking teaching materials in students' daily lives, namely through ethnomats science learning. The purpose of this research is to identify ethnomatsciences in parts of the Gunungan tradition in the Kraton Yogyakarta which can be used as a medium for learning mathematics and sanis / science. This research is a descriptive study with an ethnographic approach. Based on based on literature review, several mathematical and sanis / science concepts found in parts of the Gunungan tradition in the Yogyakarta Palace are displayed in a matrix form. The results showed that the parts of the Gunungan tradition in the Kraton Yogyakarta which are related to the concepts of mathematics and science / science include the shape of the Kakung gunungan, namely the cone, the form of the foods that make up the gunungan, the types of plants that make up the gunungan that have various elements of science / science
\end{abstract}

Keywords: Ethnomatsciences, ethnomathematics, ethnosciences, gunungan tradition.

\begin{abstract}
ABSTRAK
Proses pembelajaran pada kurikulum 2013 yang telah direvisi di tahun 2017 menekankan pada pembelajaran yang menyenangkan, bermakna, dan memotivasi siswa untuk aktif. Berdasarkan kondisi tersebut, perlu adanya pengembangan cara pembelajaran. Jadi, diperlukan inovasi pembelajaran yang menggunakan pendekatan budaya dengan mengaitkan materi ajar dalam kehidupan sehari-hari siswa yaitu melalui pembelajaran etnomatsains. Tujuan dari penelitian ini adalah untuk mengidentifikasi etnomatsains pada bagian-bagian dari tradisi Gunungan di Kraton Yogyakarta yang dapat dijadikan sebagai media pembelajaran matematika maupun sains/IPA. Penelitian ini merupakan penelitian deskriptif dengan pendekatan etnografi. Berdasarkan hasil tinjauan pustaka diperoleh beberapa konsep matematika maupun sanis/IPA yang terdapat pada bagian-bagian dari tradisi Gunungan di Kraton Yogyakarta yang ditampilkan dalam bentuk matriks. Hasil Penelitian menunjukkan bahwa bagian-bagian pada tradisi Gunungan di Kraton Yogyakarta yang berkaitan dengan konsep matematika maupun sains/IPA antara lain bentuk pada gunungan Kakung yaitu kerucut, bentuk makanan-makanan penyusun gunungan, jenis-jenis tumbuhan penyusun gunungan yang memiliki berbagai unsur sains/IPA.
\end{abstract}

Kata kunci: Etnomatsains, etnomatematika, etnosains,tradisi gunungan.

\section{PENDAHULUAN}

Proses pembelajaran pada kurikulum 2013 yang telah direvisi di tahun 2017 menekankan pada pembelajaran yang menyenangkan, bermakna, dan memotivasi siswa untuk aktif. Kurikulum 2013 merupakan kurikulum yang menekankan pembelajaran secara interaktif, inspiratif, menyenangkan, menantang, memotivasi peserta didik untuk berpartisipasi aktif, serta memberikan ruang yang cukup bagi prakarsa, kreativitas, dan kemandirian sesuai dengan bakat, minat, dan perkembangan fisik 
serta psikologis peserta didik sesuai dengan yang tersurat di dalam standar proses (Richardo, 2017). Kebermaknaan dapat dicapai jika pendidik mampu menghubungkan dengan pengalaman siswa, kehidupan sosial, lingkungan nyata, bahkan pada ranah seni dan budaya setempat. Pembelajaran matematika dan Ilmu pengetahuan alam/Sains sering dianggap siswa sebagai pembelajaran yang sulit (Prihastari \& Widyaningrum, 2018). Kondisi ini berdampak pada rendahnya prestasi matematika dan ilmu pengetahuan alam siswa Indonesia pada beberapa penilaian seperti PISA dan TIMSS. Pembelajaran Matematika dan ilmu pengetahuan alam/Sains secara umum masih berpusat pada materi dalam buku. Masih jarang pembelajaran matematika dan ilmu pengetahuan alam yang benar-benar mengungkap realita budaya disekitar siswa. Konten materi yang diajarkan pun belum banyak yang mengintegrasikan dengan budaya. Keseimbangan pembelajaran antar konsep yang ada di sekolah dengan budaya tradisional diperlukan dalam mewujudkan pembelajaran kontekstual sesuai dengan harapan kurikulum 2013 (Tanu, 2005). Seorang guru memiliki peran penting dalam mentransformasi pembelajaran matematika berbasis budaya. Sehingga pembelajaran bisa diterima lebih mudah, dekat dengan kehidupan sehari-hari siswa, dan tidak terkesan sebagai sesuatu hal baru yang jauh dari kehidupan nyata (Abdullah, 2016).

Berdasarkan kondisi tersebut, perlu adanya pengembangan cara pembelajaran. Salah satunya yaitu pendekatan pembelajaran yang kontekstual, sehingga mampu menciptakan suasana pembelajaran matematika dan sains yang penuh makna seperti dalam kehidupan sehari-hari (Herlina, 2020). Budaya lokal merupakan salah satu wujud nyata dan dapat dijumpai dalam kehidupan sehari-hari yang bisa dijadikan sebagai pembelajaran kontekstual. Jadi, diperlukan inovasi pembelajaran yang menggunakan pendekatan budaya dengan mengaitkan materi ajar dalam kehidupan seharihari siswa yaitu melalui pembelajaran etnomatsains. Etnomatsains merupakan kolaborasi antara etnomatematika dengan etnosains, yaitu pembelajaran yang mengaitkan budaya lokal dengan muatan Matematika dan Sains/IPA (Prihastari \& Widyaningrum, 2018). Etnosains merupakan kegiatan mentransformasikan antara sains asli masyarakat dengan sains ilmiah (Novitasari, dkk. 2017). Pendekatan etnosains sebagai Pendekatan etnosains merupakan proses rekonstruksi sains asli yang berkembang di masyarakat untuk diubah menjadi sains ilmiah (Khoiri \& Sunarno, 2018). Etnomatematika merupakan salah satu kajian dalam pendidikan matematika yang mengaitkan matematika dengan budaya dimana siswa tinggal. Dalam etnomatematika, siswa bukan hanya diajak untuk mengembangkan kemampuan matematika saja, tetapi siswa juga diperkenalkan dengan budaya yang merupakan karakter asli bangsanya (Bakhrodin, Istiqomah \& Abdullah, 2019). Hadirnya etnomatematika memberikan nuansa bahwa belajar matematika tidak hanya dipelajari di dalam kelas tetapi di luar kelas dengan mengunjungi atau berinteraksi dengan kebudayaan setempat dan dapat digunakan sebagai media pembelajaran matematika (Martyanti \& Suhartini, 2018). Agar dapat mewujudkan pembelajaran tersebut, maka terlebih dahulu diperlukan identifikasi, eksplorasi peninggalan budaya lokal yang berpotensi adanya keterkaitan dengan konsep-konsep dalam Matematika dan Sains.

Beberapa penelitian yang terkait peninggalan budaya lokal yang sudah tereksplorasi baik berupa bangunan sejarah, kesenian, maupun adat istiadat tetapi masih sebatas konteks matematika saja (Rohayati, Karno, 2017) atau ilmu pengetahuan alam saja (Atmojo, 2018). Urgensi dari penelitian ini yaitu untuk mengidentifikasi tradisi Gunungan di Kraton Yogyakarta yang berkaitan dengan konsep-konsep matematika digabungkan degan IPA secara bersamaan, atau lebih dikenal dengan istilah etnomatsains. Hasil dari penelitian ini dapat dijadikan bahan ajar dan media pembelajaran matematika dan sains/IPA dengan memanfaatkan kearifan lokal dan bersifat kontekstual. Dengan demikian pembelajaran di sekolah menjadi lebih menyenangkan, bermakna, dan memotivasi siswa untuk lebih aktif. Pembelajaran matematika maupun ilmu pengetahuan alam bisa bersifat kontekstual dan tidak abstrak lagi. Selain itu, siswa menjadi lebih mengenal budaya setempat dan memahami ilmu pengetahuan yang terkandung dalam tradisi maupun budaya yang ada di sekitar tempat tinggal. 


\section{METODE PENELITIAN}

Penelitian ini merupakan penelitian deskriptif dengan pendekatan etnografi yaitu mendeskripsikan dan menganalisis tentang peninggalan kebudayaan melalui studi pustaka. Sehingga ditemukan bentuk dari bagianbagian dalam tradisi Gunungan di Kraton Yogyakarta yang dapat dijadikan media untuk memahami konsep-konsep matematika maupun sains/ilmu pengetahuan alam. Studi etnografi menitikberatkan pada aspek kebudayaan masyarakat, di mana secara klasifikasi termasuk kedalam penelitian kualitatif. Teknik pengambilan data dalam penelitian ini adalah pengumpulan data pustaka yang diperoleh dari studi literatur seperti buku, jurnal, dan sumber literatur lain. Dari hasil studi literatur ini dibuat catatan, selanjutnya dilakukan analisis.

Analisis data dalam penelitian ini meliputi analisis domain dan taksonomi. Analisis domain dilakukan guna memperoleh gambaran umum dan menyeluruh dari objek penelitian disertai penentuan domain dan pengelompokan data sesuai domain. Pada penelitian ini data yang terkait dengan konsep-konsep matematika dikelompokkan pada domain etnomatematika khususnya geometri, sedangkan data yang terkait dengan konsep-konsep sains/ilmu pengetahuan alam dikelompokkan pada domain etnosains khususnya biologi dan fisika. Selanjutnya analisis taksonomi dilakukan dengan cara menjabarkan domain-domain yang telah dipilih menjadi lebih terperinci berdasarkan konsep-konsep geometri, biologi, dan fisika yang terdapat pada bagian-bagian tradisi Gunungan di Kraton Yogyakarta yang ditampilkan dalam bentuk matriks.

\section{HASIL DAN PEMBAHASAN}

Upacara Garebeg merupakan salah satu tradisi di Keraton Yogyakarta. Garebeg dilakukan pada perayaan hari besar umat Islam yakni Idul Fitri (Garebeg Syawal), Idul Adha (Garebeg Besar), Maulid Nabi (Garebeg Mulud). Upacara Garebeg selalu identik dengan Pareden (Gunungan), artinya bahwa Keraton Yogyakarta menjaga tradisi dan budaya nenek moyang. Pelestarian tradisi ini dilakukan dengan memberikan Pareden (Gunungan), kepada masyarakat (Kuncoroyakti, 2018). Ada enam macam gunungan, yakni Gunungan lanang, Gunungan wadon, Gunungan gepak, Gunungan pawuhan, Gunungan darat, Gunungan kutug/bromo. Dari keenam macam gunungan ini, yang selalu disajikan dalam setiap garebeg hanya lima macam, yakni; gunungan lanang, gunungan wadon, gunungan gepak dan gunungan pawuhan serta gunungan darat. Sedangkan gunungan kutug/bromo hanya dibuat setiap delapan tahun apabila bertepatan dengan tahun Dal, untuk disajikan dalam selamatan negara Garebeg Mulud Dal. Makanan yang digunakan sebagai komponen gunungan terdiri dari beragam jenis kue dan hasil pertanian. Jenis makanan tersebut adalah kucu, upil-upil, tlapukan, rengginan, sabunan, tedheng, eblek, bethetan, ilat-ilatan, ole-ole, badheran, bendhul, sangsangan, dhengul, pelokan, tangkil kacang, cabai merah, cabai hijau (Soelarto, 1980). Dalam tradisi gunungan di Kraton Yogyakarta, gunungan keluar dari kraton di bawa ke alun-alun untuk dipersembahkan kepada masyarakat dengan diiringi oleh para prajurit sambil memainkan gendhing keprajuritan masing-masing. Gending merupakan bentuk komposisi musikal karawitan yang menyajikan seni suara instrumental khas kraton yogyakarta.

Berdasarkan analisis hasil literasi tentang tradisi Gunungan di Kraton Yogyakarta diperoleh bagian-bagian yang memiliki aspek matematika maupun sains/IPA yang dapat dikaitkan dengan materi-materi matematika dan sains/IPA di sekolah. Adapun bagian-bagian pada tradisi Gunungan di Kraton Yogyakarta yang berkaitan dengan konsep-konsep matematika maupun sains/IPA antara lain bentuk pada gunungan Kakung yaitu kerucut, bentuk makanan-makanan penyusun gunungan, jenis-jenis tumbuhan penyusun gunungan yang memiliki berbagai unsur sains/IPA (Tabel 1).

Masih banyak bagian-bagian pada tradisi Gunungan di Kraton Yogyakarta yang bisa diintegrasikan dengan konsep matematika maupun sains/IPA. Peran guru matematika maupun sains/IPA sangat penting dalam mentransformasi pembelajaran matematika dan sains/IPA berbasis budaya. Dengan demikian etnomatsains bisa digunakan sebagai media pembelajaran yang menarik dan menyenangkan untuk penyampaian konsep matematika maupun sains/IPA dengan memanfaatkan kearifan lokal. 
Tabel 1. Daftar bagian-bagian dalam tradisi Gunungan di Kraton Yogyakarta

\begin{tabular}{|l|ll}
\hline \multicolumn{2}{c}{ Etnomatsains } & \multicolumn{1}{c}{ Domain } \\
\hline & Matematika & Gunungan Kakung/Pria yang memiliki \\
(Konsep & $\begin{array}{l}\text { bentuk seperti gambar disamping bisa } \\
\text { digunakan untuk mengenalkan konsep }\end{array}$ \\
Kerucut) & & $\begin{array}{l}\text { Kerucut kepada siswa. Kerucut adalah } \\
\text { bangun ruang yang dibatasi oleh suatu } \\
\text { daerah pada bidang datar (disebut alas) } \\
\text { dan sebuah selimut. }\end{array}$ \\
& & \\
& &
\end{tabular}

Matematika Rengginang merupakan salah satu (Konsep makanan penyusun Gunungan Dharat Lingkaran) yang bisa dijadikan media untuk mengenalkan konsep lingkaran kepada siswa. Lingkaran adalah bangun datar dimana untuk setiap titik pada lingkaran itu mempunyai jarak yang sama terhadap suatu titik tertentu yang disebut pusat lingkaran. Jarak yang sama itu disebut jari-jari.

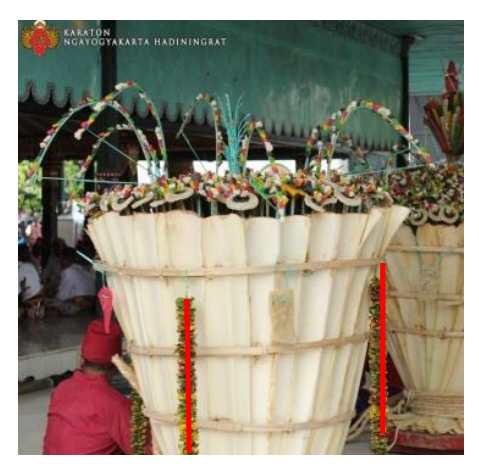

Matematika Buntal atau hiasan yang dipasang pada (Konsep Gunungan Pawuhan ini bisa digunakan Garis sejajar) media untuk mengenalkan konsep garis yang saling sejajar. Dua garis dikatakan sejajar apabila garis-garis tersebut terletak pada satu bidang datar dan tidak akan pernah bertemu atau berpotongan jika garis tersebut diperpanjang sampai tak berhingga.

Buntal di Gunungan Pawuhan

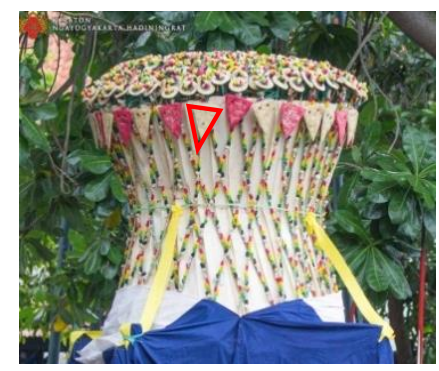

Matematika (Konsep Segitiga)
Tedheng merupakan salah satu makanan penyusun Gunungan Brama yang memiliki bentuk segitiga. Segitiga adalah bangun datar yang mempunyai tiga sisi yang ujungnya saling bertemu dan membentuk tiga buah sudut. Jumlah ketiga sudut dalam segitiga adalah 180 .

Tedheng di Gunungan Brama 


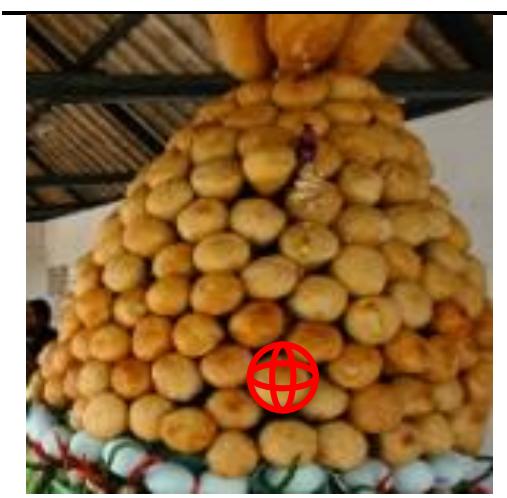

Bendhul di Gunungan Kakung

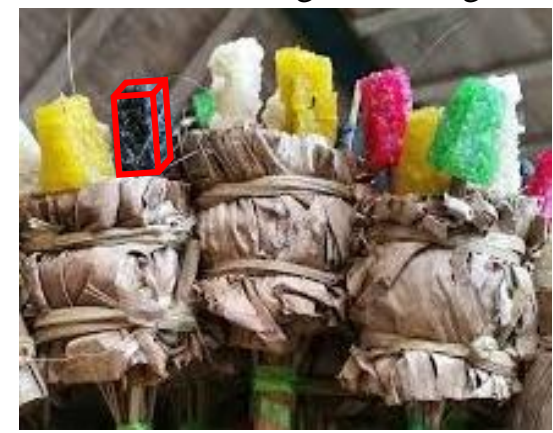

Upil-upil di Gunungan Estri

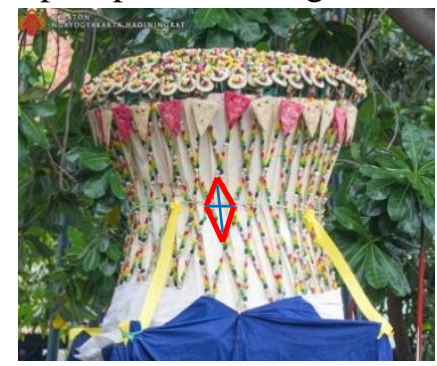

Rangkaian Ole-ole di Gunungan Brama

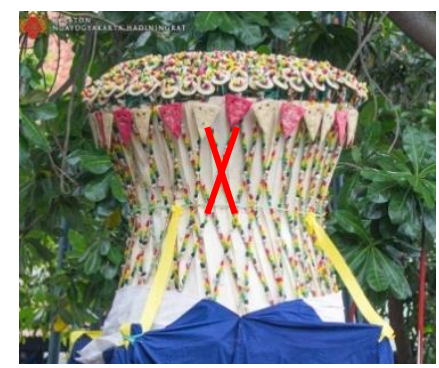

Rangkaian Ole-ole di Gunungan Brama

\begin{abstract}
Matematika Bendhul merupakan salah satu makanan (Konsep penyusun Gunungan Kakung yang Bola) memiliki bentuk seperti bola. Bola adalah himpunan semua titik dengan ruang dengan jarak tertentu dari suatu titik tetap yang disebut pusat, dan jarak tersebut dinamakan jari-jari.
\end{abstract}

Matematika Upil-upil merupakan makanan (Konsep penyususn gunungan yang terbuat dari Balok) ketan dan dipotong-potong membentuk balok. Balok adalah bangun ruangtiga dimensi yang dibentuk oleh tiga pasang persegi atau persegi panjang, dengan paling tidak satu pasang di antaranya berukuran berbeda. Balok memiliki 6 sisi, 12 rusuk dan 8 titik sudut.

Matematika Rangkaian Ole-ole yang disusun seperti (Konsep jaring yang mengelilingi Gunungan Layang- Brama ini bisa dijadikan media untuk layang) mengenalkan konsep bangun layanglayang. Layang-layang adalah bangun datar segiempat yang kedua diagonalnya berpotongan tegak lurus dan membentuk sudut siku-siku. Sifat dari layang-layang antara lain sepasang sisi yang sama panjang, sepasang sudut berhadapan sama besar, 2 diagonal yang tidak sama panjang dan berotongan saling tegak lurus.

Matematika Rangkaian Ole-ole tersebut juga bisa (Konsep digunakan untuk mengenalkan konsep Garis saling garis yang berpotongan. Dua garis berpotongan) dikatakan saling berpotongan apabila garis tersebut terletak pada satu bidang datar dan mempunyai satu titik potong. Adapun besar sudut yang bertolak belakang pada garis saling berpotongan adalah sama besar. Sedangkan sudut yang saling berpelurus jumlahnya adalah 180 derajat. 


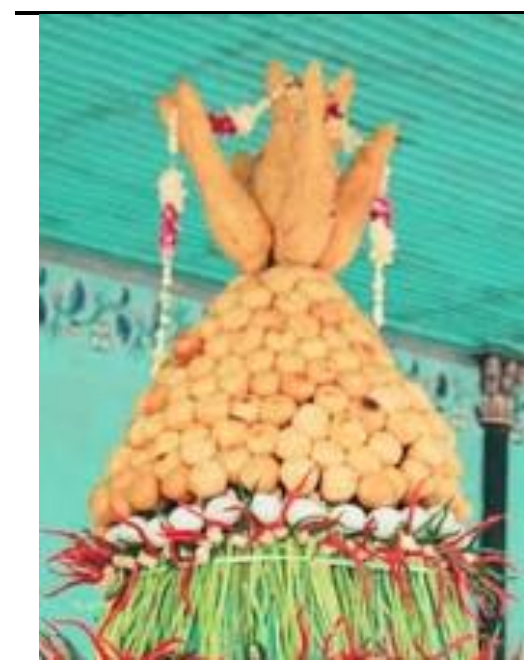

Baderan dan Bendhul di Gunungan Kakung/Pria

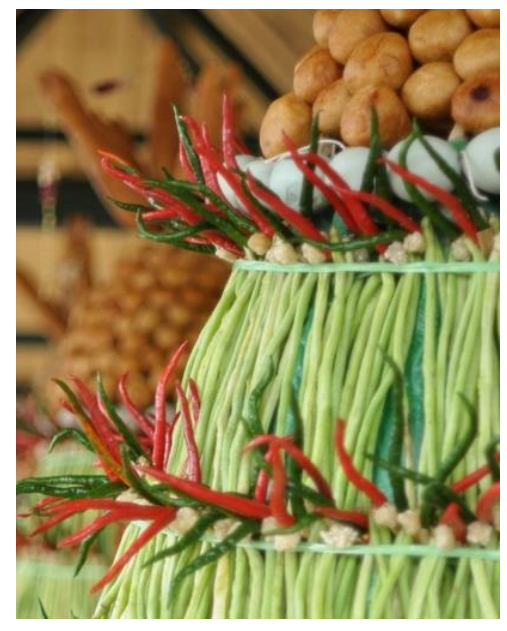

Kacang panjang, cabai, telur asin di Gunungan Kakung/Pria

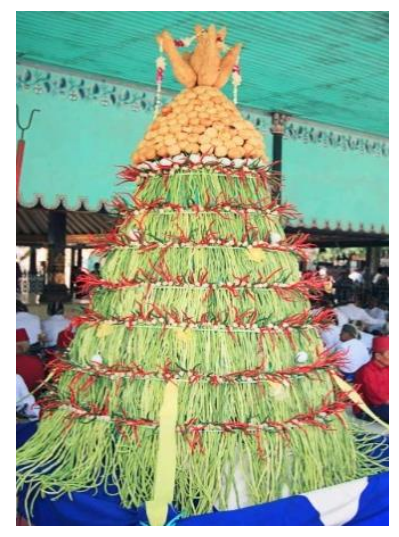

Kacang panjang, cabai, padi di Gunungan Kakung/Pria

\begin{abstract}
Biologi Puncak Gunungan Kakung terdapat
(Konsep Zat mustoko kue yang disebut dengan

Makanan dan Baderan. Baderan merupakan sumber Fungsinya karbohidrat karena terbuat dari tepung

$\underline{\text { bagi }}$

Manusia) bola-bola kecil yang disusun rapi melingkar, yang disebut dengan bendul. Bendul juga terbuat dari tepung beras dan merupakan sumber karbohidrat bagi tubuh. Karbohidrat merupakan sumber energi utama bagi tubuh. Setiap molekul karbohidrat terdiri dari karbon, hidrogen, dan oksigen. Satu gram karbohidrat menghasilkan sekitar 4,1 kilo kalori (kkal).
\end{abstract}

Biologi Kacang panjang merupakan salah satu (Konsep komponen penyusun Gunungan Kakung Vitamin) yang memiliki banyak vitamin. Sayur ini banyak mengandung vitamin $\mathrm{A}$, vitamin $\mathrm{B}$, dan vitamin $\mathrm{C}$.

Cabai yang dipasang melingkari gunungan dan berdekatan dengan kacang panjang memiliki kandungan Vitamin C. Telur asin yang dipasang setelah kue bendul pada Gunungan Kakung juga memiliki kandungan vitamin A, Vitamin B, Vitamin K.

Biologi Tumbuhan-tumbuhan penyusun (Konsep gunungan antara lain kacang panjang, Tumbuhan cabai, dan padi(bahan pada kue-kue). Monokotil Tumbuhan padi termasuk dalam dan Dikotil) tumbuhan monokotil. Sedangkan tumbuhan kacang panjang dan cabai merupakan tumbuhan dikotil. Tumbuhan monokotil merupakan tumbuhan yang memiliki biji tunggal tidak terbelah atau hanya berkeping satu. Sedangkan Tumbuhan dikotil merupakan tumbuhan yang memiliki biji berkeping dua. 


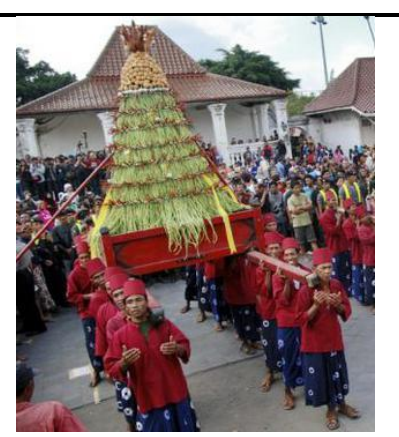

Gunungan Kakung/Pria

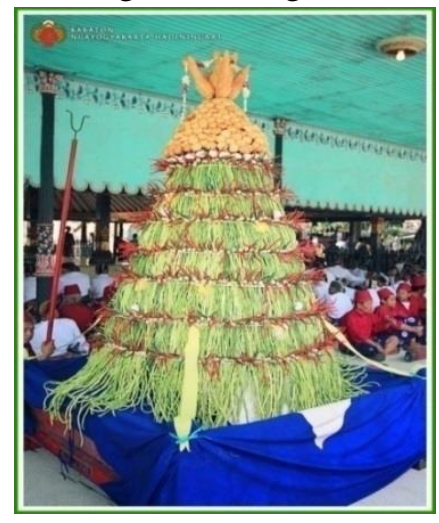

Gunungan Kakung/Pria

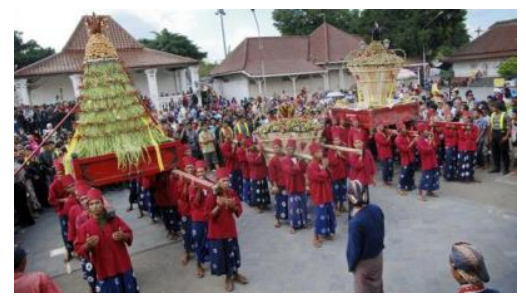

Gunungan Kakung/Pria

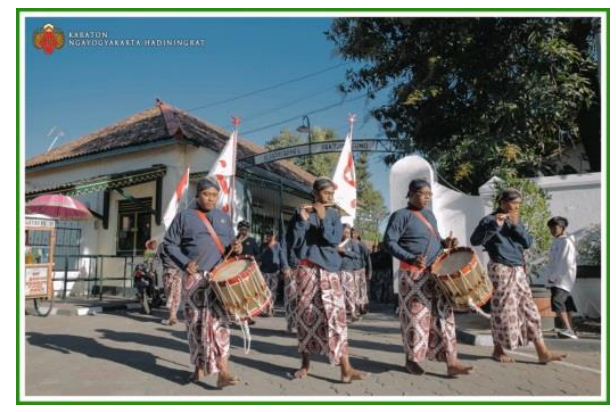

$\begin{array}{ll}\text { Fisika } & \text { Kekuatan memanggul gunungan } \\ \text { (Konsep } & \text { tidak terlepas dari teori dalam } \\ \text { Gaya) } & \text { mengangkat beban berat tersebut. } \\ & \text { Secara pengetahuan sains, teori ini } \\ & \text { dapat dipelajari pada bab gaya. Gaya } \\ & \text { adalah suatu yang dapat mengakibatkan } \\ & \text { terjadinya perubahan kecepatan dan } \\ & \text { perubahan bentuk suatu benda. }\end{array}$

Fisika

(Konsep

besaran

pokok)

Fisika

(Konsep

Gunungan Kakung memiliki ukuran panjang dan lebar $2 \times 1$ meter dengan diameternya 2 meter dan tingginya yaitu 1 meter. Gunungan beserta material penyusunnya memiliki massa. Panjang dan massa merupakan besaran pokok. Satuan dari besaran pokok panjang adalah meter, sedangkan satuan dari massa adalah kilogram. Besaran pokok adalah besaran yang satuannya telah ditetapkan terlebih dahulu dan tidak diturunkan dari besaran lain.

\section{besaran}

Dalam tradisi gunungan juga terkandung konsep besaran turunan yang bisa turunan luas, seperti pada luas dari gunungan, kecepatan, kecepatan para pemanggul gunungan, volume, volume dari gunungan, percepatan percepatan, langkah para pemanggul gunungan, dan gaya) kemudian gaya yang dibutuhkan untuk memanggul gunungan.

Fisika (konsep gelombang)
Bregada prajurit mengawal gunungan saat Garebeg sambil memainkan gendhing keprajuritan masing-masing. Gending merupakan bentuk komposisi musikal karawitan yang menyajikan seni suara instrumental. Gelombang Bunyi merupakan gelombang longitudinal yang merambat melalui suatu media. Terdapat tiga aspek utama pada bunyi, yaitu sumber bunyi, media perantara, dan penerima yakni telinga atau microphone. 


\section{KESIMPULAN}

Berdasarkan pembahasan diatas dapat disimpulkan bahwa konten etnomatsains yang ada pada tradisi Gunungan di Kraton Yogyakarta bisa digunakan untuk pembelajaran matematika maupun ilmu pengetahuan alam di sekolah baik berupa buku ajar maupun media pembelajaran. Dengan demikian pembelajaran matematika maupun ilmu pengetahuan alam menjadi lebih bermakna, menyenangkan, dan mampu meningkatkan motivasi siswa dalam belajar matematika dan ilmu pengetahuan alam serta dapat menanamkan nilai-nilai kearifan lokal kepada siswa. Siswa menjadi lebih bangga dan mampu memaknai nilai-nilai budaya bangsa dengan ilmu pengetahuan yang dimilikinya.

\section{UCAPAN TERIMA KASIH}

Terimakasih disampaikan kepada Kemendikbud dan Universitas Alma Ata yang telah mendanai dan membimbing penelitian ini melalui Program Kreativitas Mahasiswa (PKM).

\section{DAFTAR PUSTAKA}

Abdullah, A. A. (2016). Peran Guru Dalam Mentransformasi Pembelajaran Matematika Berbasis Budaya. Prosiding Seminar Matematika Dan Pendidikan Matematika, (November), 640-652. Retrieved from http://www.jurnal.fkip.uns.ac.id/index.php/ snmpm/article/view/10895

Atmojo, S. E. (2018). Pengembangan Perangkat Pembelajaran Ipa Terpadu Berpendekatan Etnosains. Jurnal Pendidikan Sains (JPS), 6(1), 5.

Bakhrodin, Istiqomah, U., \& Abdullah, A. A. (2019). Identifikasi Etnomatematika Pada Masjid Mataram Kotagede Yogyakarta. Soulmath;Jurnal Ilmiah Edukasi Matematika, 7(2), 113-124.

Herlina. (2020). Upaya Meningkatkan Aktivitas dan Hasil Belajar Kimia dengan Pendekatan Contextual Teaching Learning di Kelas X SMAN 7 Rejang Lebong. PENDIPA Journal of Science Education, 4(1), 24-30.
Khoiri \& Sunarno. (2018). Pendekatan etnosains dalam tinjauan fisafat. SPEKTRA: Jurnal Kajian Pendidikan Sains, IV(02), 145-153.

Kuncoroyakti, Y. A. (2018). Komunikasi ritual Garebeg Di Keraton Yogyakarta. Jurnal Aspikom, 3(4), 623-633.

Martyanti, A., \& Suhartini, S. (2018). Etnomatematika: Menumbuhkan Kemampuan Berpikir Kritis Melalui Budaya Dan Matematika. IndoMath: Indonesia Mathematics Education, 1(1), 35.

Novitasari, Agustina, Sukesti, Nazri, \& H. (2017). Makalah Pendamping ISSN : 25276670 Fisika , Etnosains, dan Kearifan Lokal dalam Pembelajaran Sains. Prosiding Seminar Pendidikan Fisika III, Prodi Pendidikan Fisika, FKIP, Universitas PGRI Madiun, 81-88.

Prihastari \& Widyaningrum. (2018). Analisis etnomatsains pada pembelajaran tematik sekolah dasar di kecamatan laweyan. LPPM - Universitas Negeri Surabaya, 4(18), 211219.

Richardo, R. (2017). Peran Ethnomatematika Dalam Penerapan Pembelajaran Matematika Pada Kurikulum 2013. LITERASI (Jurnal Ilmu Pendidikan), 7(2), 118.

Rohayati, Karno, \& C. (2017). Identifikasi etnomatematika pada masjid agung di yogyakarta. Prosiding. Seminar Nasional Pendidikan Matematika, 1-8.

Soelarto. (1980). Garebeg Di Kesultanan Yogyakarta. Jakarta: Direktorat Jenderal Kebudayaan Departemen Pendidikan dan Kebudayaan.

Tanu, I. K. (2005). Pembelajaran berbasis budaya dalam meningkatkan mutu pendidikan di sekolah. Jurnal Penjaminan Mutu, 2(1), 34-43. 